\title{
THE JOB SECTORS THAT AFFECTING THE EMPLOYMENT RATE OF DISABLED PEOPLE IN ASIA AND PACIFIC COUNTRIES
}

\author{
Bayu Sutikno
}

Sriwijaya University, Indonesia

\begin{abstract}
Disabled people certainly have a same opportunity to pursue their career life through working in the certain job sector that is suitable based on their abilities and skills. Employment rate of disabled people expresses the percentage number of disabled people who have successfully been producing the salary income. Therefore, this study aimed to identify the significant job sector that could give the real influence to the employment rate of disabled people in order to they know the appropriate job sector. Those job sectors were determined by applying the multiple linier regression equation with classical assumption test. Anyway, the data in this study was adopted from United Nations publication for employment rate of disabled people in Asia and Pacific countries 2015. The result showed that services and industries sector have the positive significant impact to the employment rate of disabled people with the adjusted coefficient determination value reveals to $85 \%$.
\end{abstract}

Keywords: employment rate of disabled people, services, industries, multiple linier regression

\section{Research Background}

Disabiliy refers to the abnormality condition of body in conducting the activity in daily life so this matter can affect to the mobility (Gannon B. and Brian N., 2006). This condition leads to the disabled people need the special assistance to maintain their eagerness to undertake their activities in social life. Anyway, an enormous spirit and positive thinking must be owned by the disabled people in mind because they have to compete with the normal people whatever their backgrounds and obstacles. Therefore, the outstanding skill absolutely is needed to support and assist them to survive in this life so that later, they could state the disabled people have splendid ability as well as the normal people have.

Particularly in occupation field, disabled people certainly have a same opportunity to pursue the bright future career in attaining the highest position at any interest area (Quinn G., et.al., 2002).

* Corresponding author: Bayu Sutiko

bayusutikno0@gmail.com

Published online at http://IJDS.ub.ac.id/2018

Copyright () 2018 PSLD UB Publishing. All Rights Reserved
This phenomenon creates the appreciation to the disabled people who is assessed by the quality, not by the physical form. In the job chance, they tend to select the certain sector because they want to adjust their body conditions and abilities in accomplishing the duty. Through this way, the adjustment of this chore place would influence directly in upgrading the employment rate of disabled people so there is no term to say that disabled people are very close to the unemployment status in this life and discrimination to get the occupation chance because most of normal people assume that disabled people do not have an ability to produce income (World Health Organization and United Nations Economic and Social Commission for Asia and the Pacific, 2008).

Furthermore, to accommodate the desire of disabled people in enhancing their life quality, they must know and understand regarding the occupation sectors which are suitable for them. Thus, writer intends to overcome the employment rate problem of disabled people. Since, they tend to choose the job place which is not suitable so their abilities and skills would never be applied and unfortunately, they may decide to resign from that job place. Therefore, 
this problem must be addressed by seeking an appropriate sector or feasible place for disabled people work.

Moreover, the employment rate refers to the percentage of people who is working in the certain sector so this percentage owns the influence to the welfare rate of them (Perry, D.A., 2007). In this case, employment rate of disabled people is still low and need enhancement to avoid the unemployment rate can be increase. For instance, an employment rate of disabled people in the Asia and Pacific area is still low (under $50 \%$ ) which was adopted by the United Nations (UN) Publication Book entitled "Disability at a Glance 2015: Strengthening an Employment Prospects for Persons with Disabilities in Asia and the Pacific". Therefore, this study discusses this problem that comes from the available job sector for disabled people in the Asia and Pacific countries.

This study applies the several variables which indicate to the essential issue. These variables comprise of predictor variables and response variable so this will happen the correlation among variables. Since, each predictor variable has the same proportion to affect the response variable value. Anyway, UN measured the employment rate of disabled people from three sectors, namely services, agriculture, and industry. Therefore, writer intends to examine how is the impact of each variable to the employment rate of disabled people. So, the impact of predictor variables can show the suitable tendency of job sector that disabled people prefer to choose.

Services sector was included by the UN as a measurement tool to determine the employment rate of disabled people in Asia and Pacific region. This sector has the advantageous thing for the disabled people because this sector needs the hard-skill or soft-skill to cope any duty. For instance, the people who have physical disability own the ability to be a driver, customer service, hair cutter, tailor, computer technician, recreational cultural, community and personal service, clerical and administrative workers, or so on. Fortunately, this sector could give the real contribution to produce the feasible income. In addition, services sector tend to require the huge spirit and ability to overcome the problem related to their occupation fields. This phenomenon was totally different with discrimination that disabled people used to get in this life. They acquired the underestimate from society people so this could be affect to their psychology to seek a suitable job (Lock, J, 2012).

The other sector is agriculture. This sector tends to require the strong physical abilities because most of activity must be done at the rice field (Cheyns E., 2011). However, some of disabled people are able to undertake this profession to produce the benefit income to survive in this life. Notwithstanding this sector has the difficulty especially for people who have the physical deformity, but this sector could encourage the eagerness of them to prove they are able to conduct the activity like as the normal people done (Kiribaki A. et.al., 2008).

The last but not least, the other one sector is industry. This sector is like an agriculture sector which has the difficulty level to disabled people in undertaking this profession. However, it cannot be impossible if they have ability to take this way and conduct as very well. In industry field, they prefer work as a traders, business activities, construction and maintenance, machinery operators, or so forth (Poerwanti, S.D., 2017). In addition, the advantageous thing from this sector is higher salary rather than the other sectors because this sector requires the adequate skill which should suitable with the job place required and also they have to be ready to encounter the high pressure.

Afterwards, one of analysis tool that can be applied to determine the job sectors that affecting to the employment rate of disabled people is multiple linear regression analysis. This method is able to show the correlation among variables in the equation and validity value of equation model in taking of any policy later. Undoubtedly, this method can produce the accurate model which is showed by the percentage of correlation estimation.

\section{Method}

This study applies the quantitative method through the statistical analysis approaching towards the variables of study. The collection data of this study was adopted by the Economic and Social Commission for Asia and the Pacific (2015). So, the areas or regions that would be used in this study come from the Asia and Pacific countries in 2015. Writer just uses 9 countries as a sample to this study because the availability of data from the main provenience. Furthermore, multiple regression estimation

Cite this as:

Sutikno, Bayu. The Job Sectors That Affecting The Employment Rate Of Disabled People In Asia And Pacific Countries. Indonesian Journal of Disability Studies (IJDS).2018: Vol. 5(1): PP 100-105 
would be conducted by the assistance statistical software package of SPSS version 19 (Sudarmanto, R.G., 2003). Anyway, the steps by steps that must be done are:

1. Making the statistics descriptive regarding the condition or characteristics of data such as predictor variables $\left(X_{1}=\right.$ Services, $X_{2}=$ Agriculture, and $X_{3}=$ Industries) and also response variable ( $Y=$ Employment Rate).

2. Classical Assumption Test including Normality Test with Kolmogorov-Smirnov method, Autocorrelation applying Runs Test, Heteroscedasticity Test using The Gletzer Test, and Multicollinearity Test involving tolerance and VIF value (Chatterjee S. and Ali S. H., 2012).

3. Hypothesis Test reveals the influence of predictor variables to the response variable which applying Simultaneous Test with F Test and Partial Test with $\mathrm{t}$ Test (Kutner M. H., et.al., 2005).

4. Determining the percentage value of Coefficient Determination using the adjusted R square value (Weisberg S., 2005).

5. Forming the multiple linier regression equation which containing the significant predictor variables.

6. Interpretation of the result.

7. Result and Discussion

This part explains the outcome of data processing through the multiple linear regression estimation which is based on the correlation among variables to obtain the valid correlation value.

\subsection{Statistics Descriptive}

Statistics descriptive has indispensable role to get a good understanding regarding the characteristics of whole data (Kismiantini, 2010). The characteristics of data can reveal the tendency of real dissemination. In this case, the characteristics of variables can be showed on the Table 1.

Table 1. Statistics Descriptive

\begin{tabular}{|c|c|c|c|}
\hline Variable & $\begin{array}{c}\text { St. } \\
\text { Deviation }\end{array}$ & $\begin{array}{c}\text { Maximum } \\
\text { Value }\end{array}$ & $\begin{array}{c}\text { Minimum } \\
\text { Value }\end{array}$ \\
\hline$Y$ & 11.39 & 45 & 9 \\
\hline$X_{1}$ & 19.8 & 77.8 & 8.9 \\
\hline$X_{2}$ & 25.39 & 72.3 & 4.35 \\
\hline$X_{3}$ & 5.73 & 20.85 & 2.30 \\
\hline
\end{tabular}

(the whole data in percent unit)
Table 1 expresses the evidence of data characteristics from $Y$ as a response variable which indicates the employment rate of disabled people. Afterwards, predictor variables are denoted by symbols $X_{1}, X_{2}$, and $X_{3}$. In the standard deviation part, $X_{2}$ owns the highest percentage with $25.39 \%$ meanwhile the smallest percentage is $X_{3}$ with $5.73 \%$. On the other side, the most maximum percentage value is $X_{1}$ with $77.8 \%$ and then conversely, the most minimum percentage value is $X_{3}$ with $2.30 \%$.

\subsection{Classical Assumption Test \\ 3.2.1 Normality Test}

In this case, the normality test should be conducted by applying the KolmogorovSmirnov method. The purpose of this test examines the reliability of the residual distribution of data before entrancing to the next further process. The outcome of normality test can be seen on the Table 2 .

Table 2. One Sample Kolmogorov-Smirnov Test

\begin{tabular}{|c|c|}
\hline $\begin{array}{c}\text { Kolmogorov-Smirnov } \\
\mathbf{Z}\end{array}$ & Asymp. Sig. (2-tailed) \\
\hline 0.675 & 0.752 \\
\hline
\end{tabular}

By seeing from Table 2, the normality of data distribution is clear because the value of Asymp. Sig. (2-tailed) is bigger than 0.05 $(0.752>0.05)$. So, the distribution of the data on this study has been feasible to entrance the next process in getting the multiple linier regression estimation.

\subsubsection{Autocorrelation Test}

Autocorrelation test has important part to detect the relationship among residuals in the regression equation. If autocorrelation is detected in this data study, then the result of regression equation could be bias or invalid. Since, relationship among residuals leads to the standard residual value to be bigger than the real value. Anyway, the result of Autocorrelation Test applying Runs Test can be shown on Table 3.

Table 3. Runs Test

\begin{tabular}{|c|c|}
\hline Runs Z Value & Asymp. Sig. (2-tailed) \\
\hline 0.04 & 0.968 \\
\hline
\end{tabular}

Cite this as:

Sutikno, Bayu. The Job Sectors That Affecting The Employment Rate Of Disabled People In Asia And Pacific Countries. Indonesian Journal of Disability Studies (IJDS).2018: Vol. 5(1): PP 100-105 
From table 3, there is no autocorrelation problem because the Asymp. Sig. (2-tailed) value is bigger than $0.05(0.968>0.05)$. So, this can be stated that the reliability of this data is valid.

\subsubsection{Heteroscedasticity Test}

Heteroscedasticity test is related to the residual and dissemination pattern of variance value. Data must be avoided from heteroscedasticity problem because it can lead to the inconsistency of the coefficient value of slope and intercept in the equation. Therefore, homoscedasticity is required to acquire the best multiple linier regression equation. Furthermore, the outcome of the heteroscedasticity test using Gletzer Test can be seen on the Table 4.

Table 4. Gletzer Test

\begin{tabular}{|c|c|}
\hline Variable & Asymp. Sig. (2-tailed) \\
\hline$X_{1}$ & 0.355 \\
\hline$X_{2}$ & 0.215 \\
\hline$X_{3}$ & 0.383 \\
\hline
\end{tabular}

Gletzer Test reveals there is no heteroscedasticity problem or this can be stated as homoscedasticity because the value of Asymp. Sig (2-tailed) for each variable is bigger than 0.05 . So, the inconsistency value of slope and intercept in the equation shall not be happen in this data of study.

\subsubsection{Multicollinearity Test}

Multicollinearity test is conducted to examine the correlation among predictor variables in the regression equation. If there is multicollinearity problem, then the correlation between predictor variables and response variables can be invalid and bias so the intercept and slope value which has been formed by the multiple regression equation will be incorrect. Therefore, in this study, multicollinearity test which involving the tolerance and VIF value must be done. The result of multicollinearity test could be seen on the Table 5.

Based on table 5, multicollinearity problem does not occur in this data. Since, the tolerance value of each predictor variable indicates bigger than 0.1 (tolerance value $>0.1$ ), meanwhile VIF value of each variable refers the smaller than 10
(VIF value < 10). So, this data can be used to form the multiple linier regression equation.

Table 5. Collinearity Statistics

\begin{tabular}{|c|c|c|}
\hline $\begin{array}{c}\text { Predictor } \\
\text { variable }\end{array}$ & $\begin{array}{c}\text { Tolerance } \\
\text { Value }\end{array}$ & VIF Value \\
\hline$X_{1}$ & 0.781 & 1.28 \\
\hline$X_{2}$ & 0.791 & 1.26 \\
\hline$X_{3}$ & 0.84 & 1.19 \\
\hline
\end{tabular}

\subsection{Hypothesis Test}

\subsubsection{Simultaneous Test}

This test can show the minimal one of predictor variable which has the significant impact to the response variable in this study. Simultaneous test should be conducted by using $\mathrm{F}$ table criteria. Thus, the result of simultaneous test can be seen from the value of Asymp. Sig. value is $0.032<0.05$. This outcome indicates there is minimal one of the predictor variable which has the significant influence to the response variable.

\subsubsection{Partial Test}

Based on the previous simultaneous test, predictor variable in this study has the significant effect to the response variable. Therefore, partial test would able to identify how many predictor variables which have the real effect to the employment rate of disabled people. This test applies t-test with the Asymp. Sig. value of each predictor variable is shown on the Table 6.

Table 6. Coefficient

\begin{tabular}{|c|l|}
\hline Predictor Variable & Asymp. Sig. Value \\
\hline$X_{1}$ & 0.021 \\
\hline$X_{2}$ & 0.07 \\
\hline$X_{3}$ & 0.038 \\
\hline
\end{tabular}

The Asymp. Sig. Value of each predictor variable on the Table 6 expresses $X_{1}$ and $X_{3}$ which have the real significant to the employment rate of disabled people. Since, those variables are smaller than 0.05 , meanwhile the Asymp. Sig. Value of $X_{2}$ is bigger than 0.05 which indicates there is no significant influence to the response variable. 


\subsection{Coefficient Determination}

Coefficient determination is the important part to know how much the percentage of predictor variables has impact to the response variable. This value can be known by the value of adjusted R-Square. Based on the correlation among predictor variables and hypothesis test, value of adjusted R-Square is 0.75 or $75 \%$. Finally, the equation of multiple linear regression can be formed as

$$
Y=49.7+0.37 X_{1}+0.03 X_{2}+0.56 X_{3}
$$

\subsection{Interpretation}

Based on the multiple linier regression equation from the previous part, then the direction of correlation of each predictor variable to the response variable is positive. Since, the sign of whole slope value are positive. So, if $X_{1}$ (services) variable goes up one unit, then it could affect to the ascension of employment rate of disabled people value as big as 0.37 with assume the other predictor variables are constant. Furthermore, if $X_{3}$ (industries) variable rises one unit, then it could affect to the ascension of employment rate of disabled people value as big as 0.56 with assume the other predictor variables are still constant. In this case, $X_{2}$ is not explained because this predictor variable does not have the significant impact to the response variable.

\section{Conclusion}

There are 2 predictor variables that have the significant influence to the employment rate of disabled people in Asia and Pacific countries in 2015. Those variables are services and industries sector with the validity value of appropriateness in multiple regression equation is $75 \%$. Through this result, $25 \%$ the job sectors that affecting the employment rate of disabled people come from the other sectors besides service and industry variable which are not included in this study. Moreover, positive correlation of each predictor variable would affect to the percentage value of employment rate of disabled people in Asia and Pacific countries in 2015. So, this outcome has been proving the parameter variables which were used by UN to determine the percentage value of employment rate of disabled people is suitable. Notwithstanding, there is one variable which does not reveal the significant impact to the response variable, but all sectors have the advantageous influence in enhancement the quality life of disabled people particularly in services and industries sector. To put in the nutshell, this result of study could be applied to decide the next policy in empowering of disabled people who have same opportunity or right to get the suitable job in the same manner as the other people.

\section{References}

Chatterjee S. and Ali S. H. 2012. Regression Analysis by Example Fifth Edition. New Jersey : John Wiley \& Sons, Inc.

Cheyns E. 2011. Multi-stakeholder Initiatives for Sustainable Agriculture: Limits of the 'Inclusiveness' Paradigm. ResearchGate, pp. 1 -28 .

Economic and Social Commission for Asia and the Pacific. 2015. Disability at a Glance 2015 Strengthening Employment Prospects for Persons with Disabilities in Asia and the Pacific. Bangkok : United Nations.

Gannon B. and Brian N. 2006. The Dynamics of Disability and Social Inclusion. Dublin : The Equality Authority.

Kiribaki A. et.al. 2008. Report of the Evaluation of the Sustainable Agriculture for

People with Disabilities (SAPED) Programme. Uganda : Send A Cow Uganda (SACU).

Kismiantini. 2010. Handout Analysis Regresi. Yogyakarta : Jurusan Pendidikan Matematika Fakultas Matematika dan Ilmu Pengetahuan Alam Universitas Negeri Yogyakarta.

Kutner M. H., et.al. 2005. Instructor Solutions Manual to accompany Applied Linear Statistical Models Fifth Edition. Chicago : McGraw-Hill.

Lock, J. 2012. Pendapat dan Perubahan Terhadap Difabel Apakah Hidup Menjadi Lebih Muda Atau Lebih Sulit Untuk Orang Yang Cacat Dalam Masyarakat Indonesia?. Malang : 
Fakultas Ilmu Sosial dan Ilmu Politik Universitas Muhammadiyah Malang.

Perry, D.A. 2007. Employability A Resource Guide On Disability for Employers in Asia and the Pacific. Bangkok : International Labour Organization.

Poerwanti, S.D. 2017. Pengelolaan Tenaga Kerja Difabel untuk MewujudkanWorkplace Inclusion. INKLUSI: Journal of Disability Studies. 4(1) : 1 - 24 .

Quinn G., et.al. 2002. Human Rights and Disability the Current Use and Future Potential of United Nations Human Rights Instruments in the Context of Disability. New York and Geneva : United Nations.

Sudarmanto, R. G. 2003. Analisis Regresi Linear Ganda dengan SPSS. Jakarta : Graha Ilmu.

Weisberg S. 2005. Applied Linear Regression Third Edition. New Jersey : John Wiley \& Sons, Inc.

World Health Organization and United Nations Economic and Social Commission for Asia and the Pacific. 2008. Training Manual on Disability Statistics. Bangkok : United Nations. 